\title{
A new species of Bufo Laurenti (Anura, Bufonidae) from northeastern Brazil
}

\author{
Maria Nazaré Stevaux ${ }^{1}$
}

\begin{abstract}
A new species of bufonid toad, Bufo jimi sp. nov., is described from Maracás and Itagibá, State of Bahia, Brazil. This species shows close relationships to B. paracnemis Lutz, 1925 by sharing the presence of tibial glands and the paratoid glands shape. The new species is a member of the Bufo marinus-group, and is characterized by having well-defined glands in most part of dorsal face of the forearms, in the extern side of the feet and in both sides of cloacal region.

KEY WORDS. Amphibia, Anura, Bufonidae, Bufo jimi sp. nov., anuran, taxonomy
\end{abstract}

The genus Bufo Laurenti, 1768 is a group of toads with extensive distribution in the New World, Eurasia and Africa (GRAYBEAL \& CANNNATELla 1995). The marinus-group of this genus has a typical Neotropical distribution, from southern Texas in North America to southern Argentina (north of the Chubut River), extending from east of the Andes to the Atlantic coast (GALLARDO 1962; 1965a, b; CEI 1968, 1972; BLAIR 1972; REIG 1972; HOOGMOED 1990; DUELLMAN \& SCHULTE 1992).

The marinus-group is composed by six species: Bufo arenarum Hensel, 1867, B. ictericus Spix, 1824, B. marinus Linnaeus, 1758, B. paracnemis Lutz, 1925, B. poeppigii Tschudi, 1845 e B. rufus Garmann, 1877 (DUEllman \& SCHUlte 1992). Bufo paracnemis is an inhabitant of open formations of South America, from the dry Caatinga in northeastern Brazil to the Chaco region in Argentina, across the steps of Central Brazil (CEI 1972). In the Atlantic rain forests of southeastern Brazil, from Rio de Janeiro to Uruguay, there is another species of this group, B. ictericus (BLAIR 1972; CEI 1972; MARTIN 1972).

A new member of this group, distributed in northeastern Brazil, is described here and can contribute to a better understanding of the evolution of the marinus-group.

\section{MATERIAL AND METHODS}

The specimens examined are housed in JJ (Jorge Jim Collection, deposited in the Universidade Estadual Paulista, Botucatu, São Paulo, Brazil) and from the MZUSP (Museu de Zoologia, Universidade de São Paulo, São Paulo, Brazil).

A total of 25 measurements were taken in $\mathrm{mm}$ (by using of the $0,2 \mathrm{~mm}$ of precision instruments) from external feature. Abbreviations are as follows: SVL (snout-vent length), HW (head width), HL (head length), ED (eye diameter), TD (tympanum diameter), IOD ${ }^{\mathrm{f}}$ (fore inter-orbital distance), IOD $^{\mathrm{m}}$ (medial inter-orbital

1) Departamento de Biologia Geral, Universidade Federal de Goiás. Campus Samambaia, Caixa Postal 131, 74001-970 Goiânia, Goiás, Brasil. E-mail: nstevaux@uol.com.br 
distance), $\operatorname{IOD}^{\mathrm{p}}$ (posterior interorbital distance), IND (inter-nostril distance), NSD (nostril-snout distance), END (eye-nostril distance), ETD (eye-tympanum distance), PL (parotoid gland length), PW (parotoid gland width), AL (arm length), FAL (fore-arm length), HaL (hand length), ThL (thigh length), TbL (tibia length), FL (foot length), STCL (supra-tympanic crest length), EL (eyelid length), MFL (metatarsal fold length), POCL (pre-orbital crest length), and OTCL (orbit-tympanic crest length).

Morphological data were taken from comparative analysis of samples of $B$. paracnemis of the MZUSP and the JJ.

\section{Bufo jimi sp. nov.}

Holotype. JJ 7628 adult male from BRAZIL, Bahia: Maracás $\left(40^{\circ} 26^{\prime} \mathrm{W}\right.$, $13^{\circ} 26^{\prime}$ S, Fazenda Cana Brava), 10/I/1975, J. Jim, L.A. Toledo, C.M. Carvalho, S.A. Mioni \& U. Caramaschi leg.

Paratypes. BRAZIL, Bahia: Itagibá (39 $51^{\circ}$ 'W, $14^{\circ} 24^{\prime}$ 'S, Fazenda Pedra Branca), 04 a 07/II/1974, JJ-7536-40 (males); 7541-42; 7543-44 and 7545-48 (females), J. Jim \& U. Caramaschi leg.; 16-24/I/1975, 7643-46, 7650-52, 7654-56, 7668-72 (males), 7647-49, 7653, 7657-60, 7661-67, 7673-77, 7678-83 (females), J. Jim, U. Caramaschi, C.M. Carvalho \& S.A. Mioni leg.; Maracás (Fazenda Cana Brava), 10-12/I/1975, JJ-7629 (male), 7624, 7625, 7630-31, 7632-34, 7635-37, 7638 (females), J. Jim, L.A. Toledo, C.M. Carvalho, S.A. Mioni \& U. Caramaschi leg.; Maracás (Fazenda Três Barras), 13/I/1975, JJ-7639-42 (females), J. Jim, L.A. Toledo, C.M. Carvalho, S.A. Mioni \& U. Caramaschi leg.

Holotype and paratypes are housed in Jorge Jim Collection (JJ), deposited in the Universidade Estadual Paulista, Botucatu, São Paulo, Brazil.

Description of the holotype. A stout, large and weighty toad species (Fig. 1 a-b). Head (Fig. 2 a-f in female paratype) wider than long, snout rounded in profile and drawing a semicircle in ventral view. Skull very broad and concave. All cranial crests present, thick. Crest on snout thick and moderately projected. Supra-lip arcs short and thick. Canthus rostralis distinct, loreal region slightly concave; nostrils slightly protuberant and directed backwards and upwards. Eyelids thick, with edges projected and covered by several keratinized spines. Tympanum rounded, median and distinct, with scattered keratinized points at margin. Parotoid glands (Fig. 2 a-f) follow the supra-tympanic crests, broad anteriorly, slender posteriorly. Behind each gland is a line of elongated tubercles reaching the median inguinal region. No vomerine or maxillary teeth, but vomerine odontoids present. Arms moderately strong in males, slim in females; well defined forearm glands dorsally (Fig. 2a, d and indicated by arrows in figure $3 a$ from holotype). Finger length: II $<\mathrm{I}<\mathrm{IV}<\mathrm{III}$. No webbing. Subarticular tubercles double or divided. Inner metacarpal tubercle rounded, nearly elliptical. Outer metacarpal tubercle large, nearly rounded, followed by a line of small tubercles, slightly keratinized on ventral face of fore-arms. Legs robust and short. Tibiae glands irregular and scarcely defined (Fig. 1a, 3b, e). Metatarsal fold low, but thick and covered by a continuous line of keratinized points. Feet (Fig. $1 \mathrm{c}$ ) with elliptical inner metatarsal tubercle, longer than wide; subarticular tubercles small, single and rounded. Lateral surface of feet with an anterior, main, well-defined gland reaching the to toe $\mathrm{V}$, and a smaller, more scarcely defined gland 

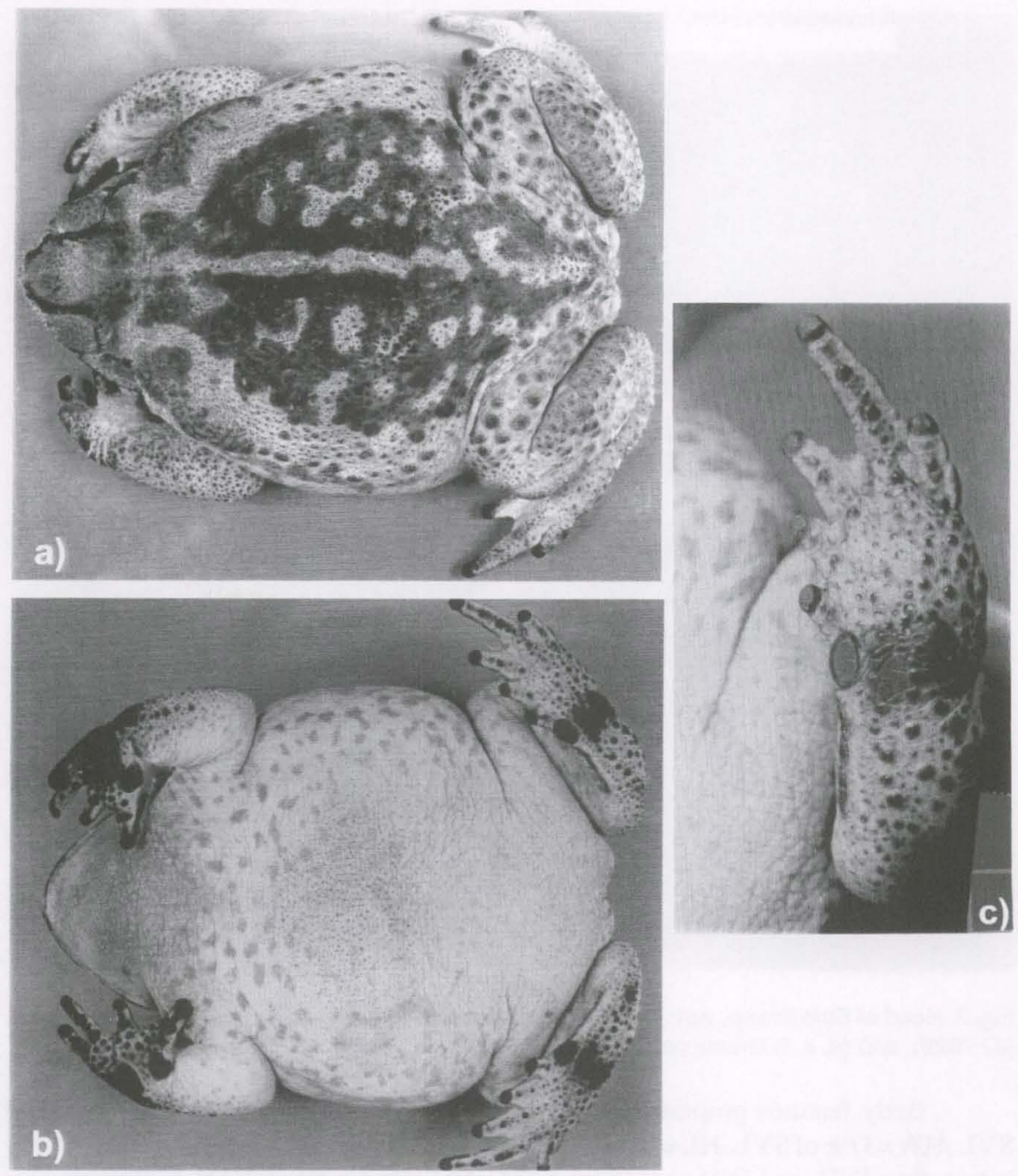

Fig. 1. Male holotype of Bufo jimi sp. nov. (JJ 7628): (a) dorsal view, (b) ventral view, and (c) ventral view of foot.

in metatarsal region (indicated by arrows in figure $3 \mathrm{~b}, \mathrm{~d}$ ). Toes webbed proximally and fringed distally. Toes length: $\mathrm{I}<\mathrm{II}<\mathrm{V}<\mathrm{III}<\mathrm{IV}$. Two evident aggregates of glands symmetrically located at both side of cloaca (Fig. $1 \mathrm{a}$, b, and indicated by arrows in Fig. 3c, e), with no defined shape, but always present.

Measurements from holotypes (in $\mathrm{mm}$ ): $\mathrm{SVL}=171 ; \mathrm{HW}=67,25 ; \mathrm{HL}=$ 42,$10 ; \mathrm{ED}=13,54 ; \mathrm{TD}=11,60 ; \mathrm{IOD}^{\mathrm{f}}=23,46 ; \mathrm{IOD}^{\mathrm{m}}=23,57 ; \mathrm{IOD}^{\mathrm{p}}=28,31 ; \mathrm{IND}$ $=10,57 ; \mathrm{NSD}=5,63 ; \mathrm{END}=11,16 ; \mathrm{ETD}=6,60 ; \mathrm{PL}=44,78 ; \mathrm{PW}=21,40 ; \mathrm{AL}=$ 47,$63 ; \mathrm{FAL}=39,38 ; \mathrm{HaL}=25,63 ; \mathrm{ThL}=69,60 ; \mathrm{TbL}=60,50 ; \mathrm{FL}=90,43 ; \mathrm{STCL}$ $=10,76 ; \mathrm{EL}=11,57 ; \mathrm{MFL}=18,40 ; \mathrm{OTCL}=15,84 ; \mathrm{POCL}=14,62$. 

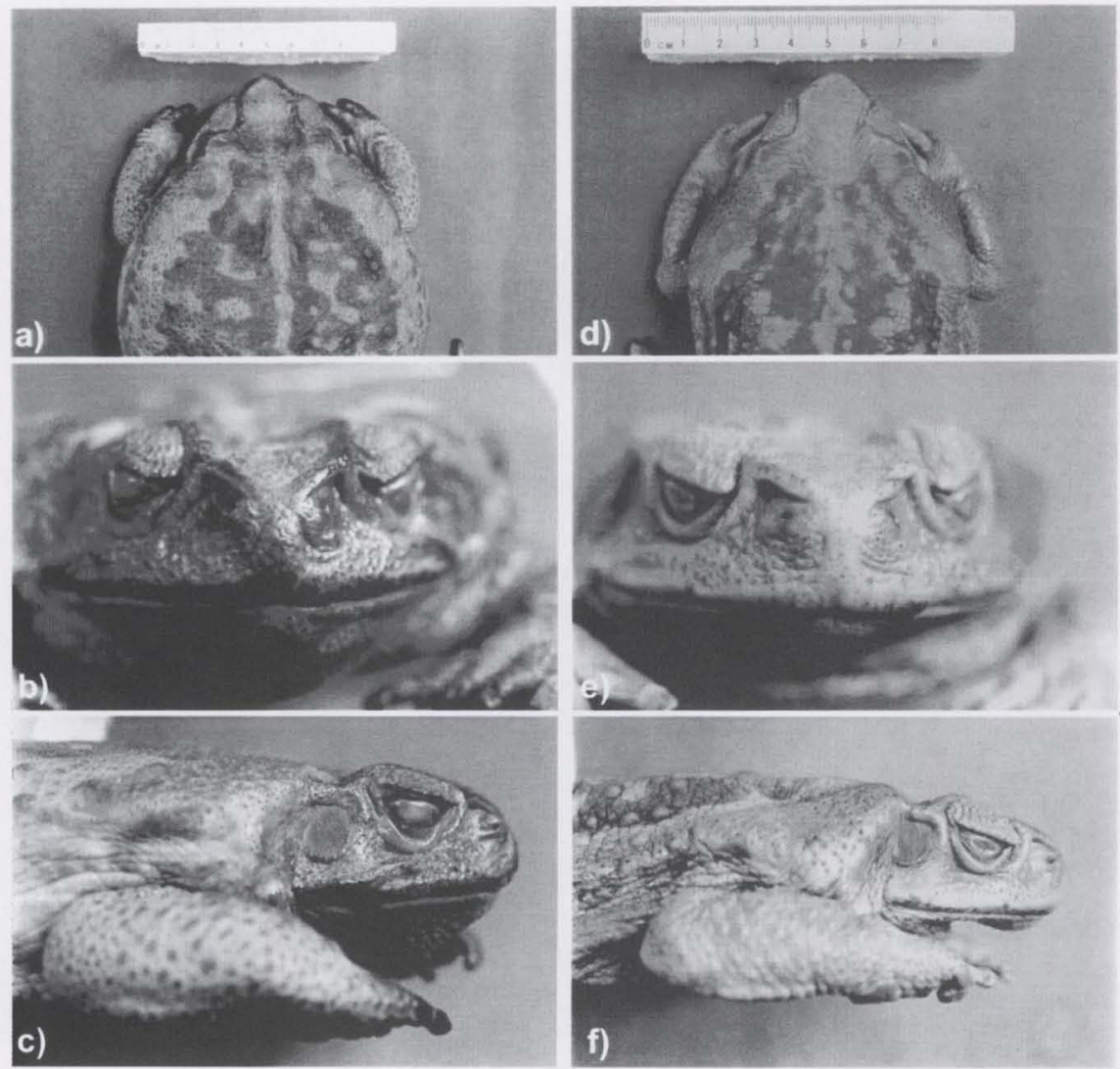

Fig. 2. Head of Bufo jimi sp. nov. in dorsal, frontal, and profile views: (a, b, c) of male holotypes (JJ 7628), and (d, e, f) female paratype (JJ 7631).

Body features proportions (Tab. I, for morphometric media). $\mathrm{HL}=25 \%$ of SVL, HW $=37 \%$ of SVL. HL $=67 \%$ of HW. OTCL $>$ STCL $>$ POCL $>$ EL. END slightly longer than IND, and IND near twice ETD. IND = twice NSD. ETD slightly greater than NSD. TD $=62 \%$ of ED, and $=41 \%$ from $\mathrm{IOD}^{\mathrm{m}} . \mathrm{ED}=76 \%$ of $\mathrm{IOD}^{\mathrm{m}}$. HaL $=67 \%$ of $\mathrm{AL}$, and $=89 \%$ of FAL. ThL $=73 \%$ of FL; TbL $=67 \%$ of FL. MFL $=24 \%$ of FL.

Color of holotype in preservative. Dorsum is grayish beige, mottled with dark brown spots nearly symmetrically distributed, from anterior end of parotoid glands to posterior region, in both sides of the body. The parotoid glands show a slightly distinct color, more orangeish. Ventrally beige is lighter than in dorsum. Head region is very dark, from brown to nearly black. Spots brown are smokiest more concentrated at the scapular region and scarcely to back.

Skin texture. Dorsum skin is covered by many tubercles of variable sizes. On dorsum, flanks, and upper surface of arms and legs, keratinized spines are present, as well as on skin, and on tubercles. These points have small spines, giving a sandpaper appearance at touch (in females these spines are absent, the skin is smoother at touch). 

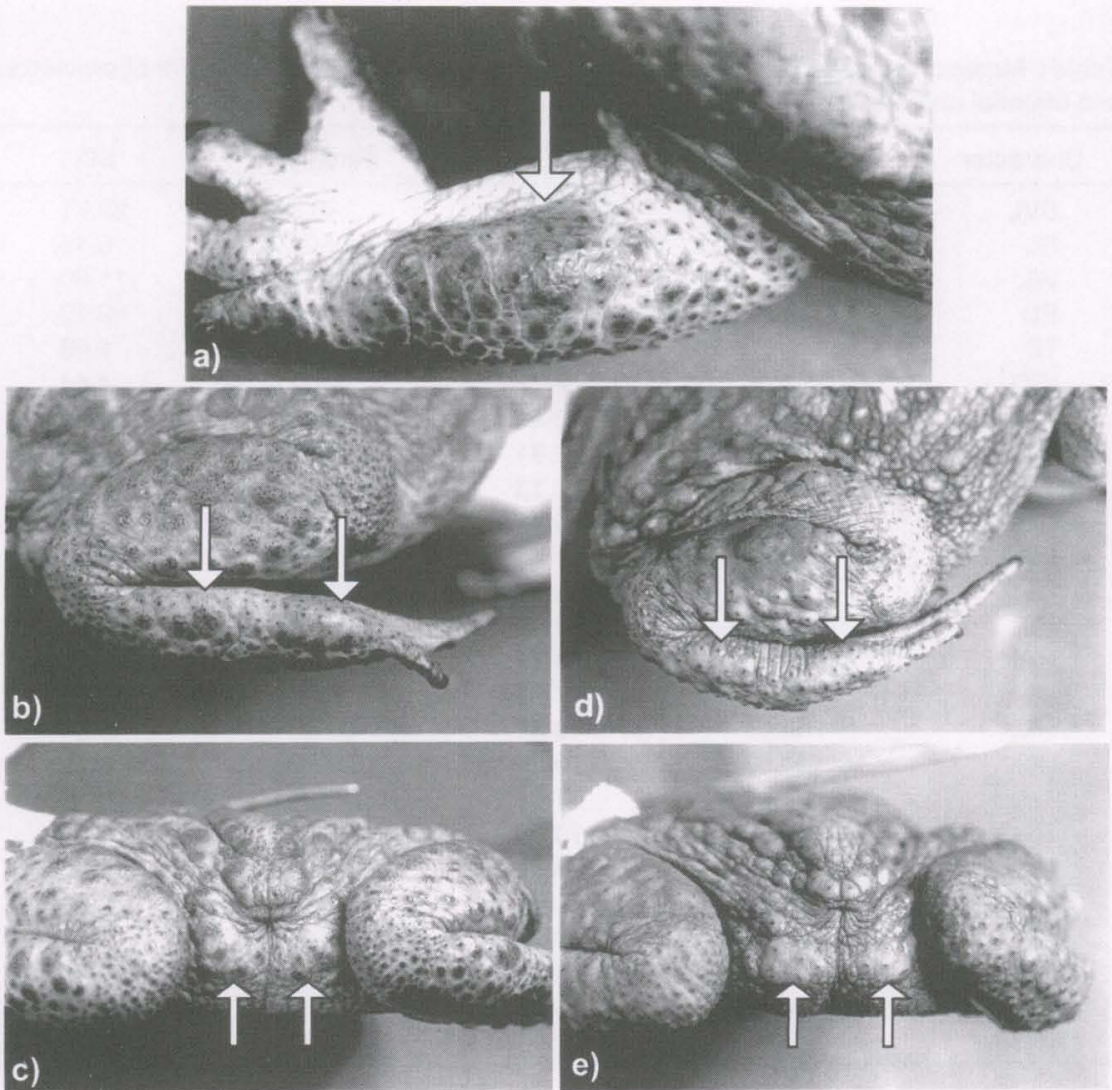

Fig. 3. Diagnostic features of Bufo jimi sp. nov.: glands on forearm, on foot, and on both sides of cloaca from (a, b, c) male holotypes (JJ 7628), and (d, e) female paratype. (JJ 7631).

Diagnosis and comparison with other species. It seems quite probable that Bufo paracnemis in its traditional sense represents a species complex. This species presents large distribution in the open formations of the South America (Fig. 4). Bufo jimi sp. nov. corresponds to the set of populations identified to date as $B$. paracnemis in the Brazilian northeastern region (Fig. 4) and clearly represents a different species. Bufo jimi sp. nov. shows close relationships to B. paracnemis, as indicate the presence of tibial glands and the parotoid gland shape. Bufo jimi $\mathbf{s p .}$ nov. differs from $B$. paracnemis on the following diagnostic features: presence of forearm gland, an external gland in the feet, and gland conglomerates on both sides of the cloaca. Additionally, in $B$. jimi sp. nov. the eyelid length is slightly shorter than in B. paracnemis. CSTL/EL proportions is 1,0 in B. jimi sp. nov., while in different localities $B$. paracnemis specimens this proportion is about $0,9(\mathrm{SD}=0.04)$. The eye diameter in B. jimi sp. nov. is $76 \%$ of the interorbital distance, while in $B$. paracnemis is $81 \%(\mathrm{SD}=4 \%)$. Hands are $89 \%$ of forearm length, smaller than in B. paracnemis $(\mathrm{M}=93 \%, \mathrm{SD}=2 \%)$. The metatarsal fold length is $24 \%$ of the foot length, slightly larger than in $B$. paracnemis $(\mathrm{M}=22 \%, \mathrm{SD}=0,47 \%)$. 
Table I. Media of measurements of samples of Bufo jimi sp. $\mathbf{n} .(\mathrm{mm})(\mathrm{N}=60)$. For abbreviations see Material and Methods.

\begin{tabular}{lrrrr}
\hline Character & Males & \multicolumn{1}{c}{ SD } & Females & SD \\
\hline SVL & 147.48 & 16.34 & 133.8 & 29.71 \\
HL & 36.63 & 3.79 & 32.94 & 6.45 \\
WL & 54.12 & 11.18 & 48.63 & 11.90 \\
ED & 14.85 & 1.59 & 13.34 & 2.43 \\
TD & 9.10 & 0.92 & 8.29 & 1.48 \\
IOD & \multicolumn{1}{c}{} & 2.72 & 18.04 & 4.44 \\
IOD & 20.60 & 2.81 & 17.46 & 4.60 \\
IOD & 19.63 & 1.91 & 20.60 & 4.88 \\
IND & 23.07 & 1.13 & 8.10 & 1.88 \\
NSD & 9.13 & 0.73 & 4.29 & 1.10 \\
END & 4.37 & 1.25 & 8.73 & 1.87 \\
ETD & 9.61 & 0.93 & 4.36 & 1.30 \\
PL & 5.01 & 4.45 & 33.19 & 9.63 \\
PW & 35.90 & 3.94 & 19.17 & 7.20 \\
AL & 22.65 & 7.35 & 4.05 & 10.58 \\
FAL & 48.11 & 5.51 & 30.80 & 8.24 \\
HaL & 36.01 & 3.80 & 28.10 & 6.22 \\
ThL & 31.67 & 7.61 & 47.98 & 12.40 \\
TbL & 54.82 & 10.00 & 45.37 & 11.39 \\
FL & 49.53 & 8.91 & 66.32 & 14.92 \\
STCL & 74.96 & 1.70 & 8.48 & 2.99 \\
EL & 9.69 & 0.91 & 8.14 & 1.81 \\
MFL & 8.57 & 3.21 & 16.34 & 4.46 \\
POCL & 17.16 & 1.46 & 9.74 & 2.36 \\
OTCL & 10.68 & 1.44 & 8.21 & 2.05 \\
\hline
\end{tabular}

Bufo ictericus, from the Atlantic forests in southeastern Brazil (Fig. 4), would be slightly more distant from $B$. jimi sp. nov. The tibial glands represent a synapomorphy joining $B$. jimi sp. nov. and B. paracnemis. Bufo ictericus joins this pair of species in an immediately higher level, as suggested by osteological (MARTIN 1972), reproductive (BLAIR 1972), and morphological features (CEI 1972). On the other hand, B. marinus and B. poeppigii seem to constitute a more basal clade in the marinus-group. BLAIR's (1972) interpretation of experimental hibridization and testes proportion showed that a pair of species composed of $B$. arenarum and $B$. rufus would joined $B$. paracnemis, B. jimi sp. nov., and $B$. ictericus. The closest relationship between $B$. arenarum and $B$. rufus, sometimes referred as the arenarum-group (CEI 1972), is suggested by the smaller and more elongated parotoid glands and the proportions of the skull.

Geographic distribution. Bufo jimi sp. nov. is distributed in the entire northeastern region of Brazil, from State of Maranhão to State of Bahia at low altitudes, from sea level to nearly by $400-500 \mathrm{~m}$. No local specialization was detected between the populations examined. The distribution area of B. jimi sp. nov. includes the northern spots of rain forest along the Atlantic coast, the open formation of caatinga in Maracás (Bahia) and the dry area of Cabaceiras in State of Paraíba. 


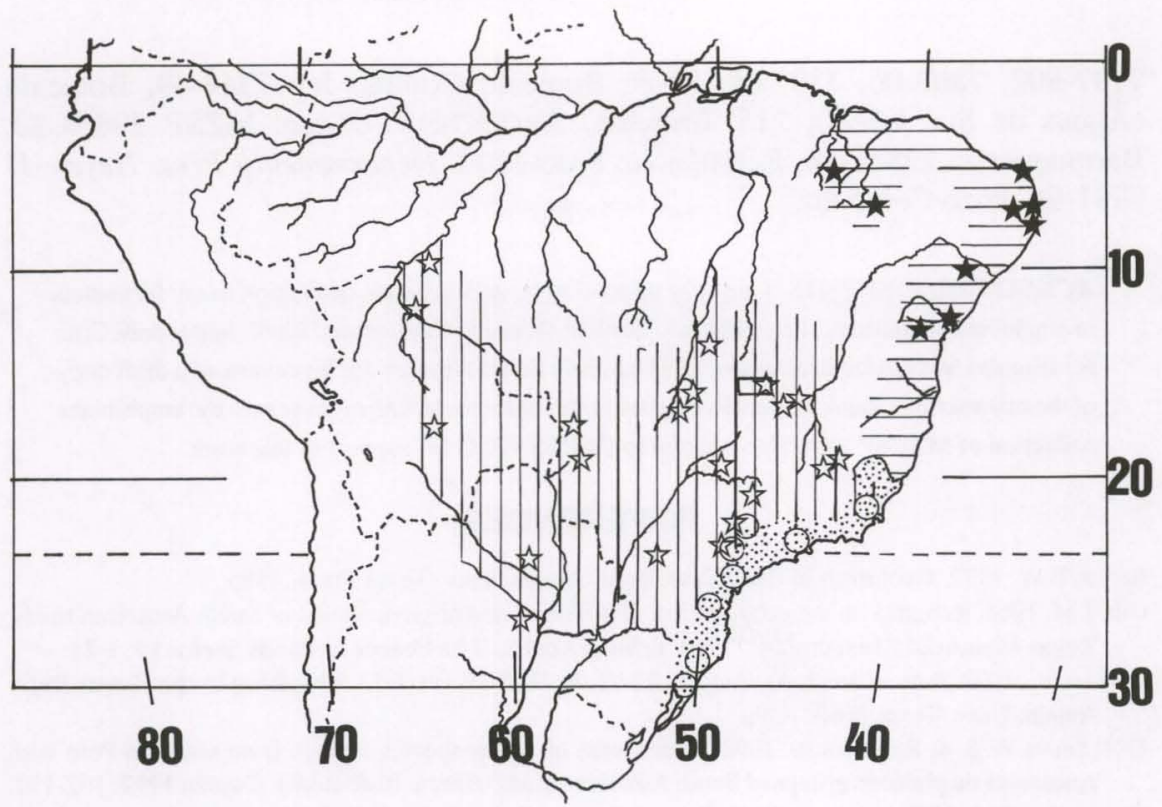

Fig. 4. Approximate area of distribution of three species: Bufo jimi sp. nov. (horizontal lines), B. paracnemis (vertical lines) and B. ictericus (spots). The circles points localities for Bufo ictericus, and stars points localities with specimens considered Bufo paracnemis (black stars $=B$. jimi, and white stars $=B$. paracnemis in this work).

Etymology. The specific name of this species is given after Dr. Jorge Jim for his contribution to the knowledge of the Brazilian herpetology.

Additional material examined. Specimens recognized as Bufo jimi sp. nov.: BRAZIL, Alagoas: MZSP 11901-09, Mangabeiras; Bahia: MZSP 10750-70, Salvador; 38054-60, Jeremoabo; Maranhão: MZSP 21236, Aldeia do Ponto; 21237-38, Barra do Corda; 21239, Tabacoal; 212748, São Luiz; Paraíba: MZSP 22909-21, Mamanguape; 62992-96, Gurinhém; Pernambuco: MZSP 24321-22, Ponta de Pedras; 55504, Recife; Piauí: JJ (unregistred) Picos; Rio Grande do Norte: MZSP 29408, Ponta Negra; Sergipe: MZSP 55488-03, Santo Amaro das Brotas; Arquipélago Fernando de Noronha: MZSP 20962-70.

Specimens recognized as B. paracnemis: Goiás: MZSP 29514-28, Jataí, 29532-35, Rio Verde, 29572-80, Santa Isabel do Morro, 71727-45, Serra da Mesa; Distrito Federal: JJ 7787-88, Brasília (Lago Paranoá); Mato Grosso: MZSP 22393 07, Xavantina; 29434-40, Três Lagoas; 29758-64, Mato Verde; Mato Grosso do Sul: MZSP 15791-96, Aquidauana; 29470-71, Serra do Urucum; Minas Gerais: MZSP 20509-18, Santana do Araçuaí; 29581-88, Arinos, 29605-08, Lagoa Santa, 29648-51, Uberlândia, 29663-71, Unaí; Paraná: MZSP 29774-84, Guairá; Rondônia: MZSP 20420-30, Porto Velho; 29791-96, Príncipe da Beira; JJ 7684-85; 7686-88 and 7689-93, Guajará Mirim; São Paulo: MZSP 11234-62, Emas; 1190109, Herculânia; 29673-81, Borborema; JJ 7771, Angatuba; 214, Anhembi; 743; 7455; 7458; 7465; 7549-50; 7551; 7552, Botucatu (Faz. Lageado); 7343; 7456-57; 
7797-802; 7803-06; 7807-08; 7809; Botucatu (Rubião Jr); 7344-49, Botucatu (Águas de Sta. Lúcia); 215, Conchas. ArgentinA, Chaco: MZSP 29864-80, Barranqueras; 29881-88, Resistência. PARAGuaI, Departamento Pres. Heyes: JJ 7791-96, Pozo Colorado.

ACKNOWLEDGEMENTS. I am very grateful to Jorge Jim by his dedication to my formation in amphibians systematic. I also thank to Benedito Rinaldo Cardana and Elieth Spirandelli Cruz for stimulus and useful discussions, and Dalton de Sousa Amorim for his review of a draft copy of the manuscript. I thank Miguel Rodrigues for his agreement with my access to the amphibians collection of MZUSP. I am also grateful to CAPES-PICD for support to this work.

\section{REFERENCES}

BLAIR, F.W. 1972. Evolution in the Genus Bufo. Austin, Univ. Texas Press, 459p.

CEI, J.M. 1968. Remarks on the geographical distribution and phyletic trends of South American toads. Texas Memorial Museum/24 $4^{\mathrm{TH}}$ and Trinity/Austin, The Pearce-Sellards Series 13: 1-21.

1972. Bufo of South America, p. 82-92. In: W.F. BLAIR (Ed.). Evolution in the Genus Bufo. Austin, Univ. Texas Press, 459p.

Duellman W.E. \& R. Schulte. 1992. Description of a new species of Bufo from northern Peru with comments on phenetic groups of South American toads (Anura: Bufonidae). Copeia 1992: 162-172.

Gallardo, J.M. 1962. A proposito de Bufo variegatus Günther, sapo del bosque húmedo antartântico, y las otras especies de Bufo neotropicales. Physis, Buenos Aires, 23: 93-102.

. 1965a. Una nueva subespecie chaqueña Bufo arenarum chaquar (Amphibia: Bufonidae). Neotropica, Buenos Aires, 11 (36): 84-88.

1965b. Especiación en tres Bufo Neotropicales (Amphibia, Anura). Papéis Avuls Depto Zoologia, São Paulo, 17 (7): 59-75.

Graybeal, A. \& D.C. Cannatella. 1995. A new taxon of Bufonidae from Peru, with descriptions of two new species and a review of the phylogenetic status of supraspecific bufonid taxa. Herpetologica 51 (2): 105-131.

HoogmoED, M.S. 1990. Biosystematics of South American Bufonidae, with special reference to the Bufo typhonius-group, p. 113-123. In: G. Peters \& R. Hutteter (Eds). Vertebrates in the Tropics. Bonn, Museum Alexander Koenig, 424p.

MARTIN, R.F. 1972. Evidence from osteology, p. 37-70. In: W.F. BLAIR (Ed.). Evolution in the Genus Bufo. Austin, Univ. Texas Press, 459p.

REIG, O.A. 1972. Macrogenioglottus and the South American bufonid toads, p. 14-36. In: W.F. BLAIR (Ed.). Evolution in the Genus Bufo. Austin, Univ. Texas Press, 459p.

Received in 21.IX.2001; accepted in 29.VI.2002. 